Raf. J. Sci.,Vol.28, No.2 Special Issue for the Third Scientific Conference of Chemistry, pp.127-134, 2019

\title{
Spectrophotometric Determination of Mesalazine
}

\author{
Safaa A. Al-Zakaria \\ Department of Chemistry/ College of Science/ University of Mosul
}

(Received 13/9/2018; Accepted 25/10/2018)

\begin{abstract}
Mesalazine (MESA) is determined by a simple and rapid visible spectrophotometric method. This method is depend on oxidative coupling reaction of mesalazine with histidine (HIS) in alkaline media using N-bromosuccinimide (NBS) as oxidizing agent to form a water soluble and stable product, that it has a maximum absorption at $459 \mathrm{~nm}$. Beer's law is followed in a concentration range of 50 to $750 \mu \mathrm{g} / 20 \mathrm{ml}(2.5-37.5 \mu \mathrm{g} / \mathrm{ml})$ with a molar absorptivity of $3.3682 \times 10^{3} 1 . \mathrm{mol}^{-1}$. $\mathrm{cm}^{-1}$. The recommended method has been successfully applied to the assay of MESA in pharmaceutical preparations.
\end{abstract}

Keywords: spectrophotometry, oxidative coupling, mesalazine, histidine.

\section{القير اللمي لالميزالازن}

\section{الملغص}

يتضمن البحث طريقة طيفية بسيطة وسريعة لقدير الميزالازين (MESA). تعتمد الطرريقة على قفاعل الاكسدة والاقتران للميزالازين مع الهستين(HIS) في وسط قاعدي بلستخدلم ن_بروموسكسينلميد (NBC) بوصفه علملا' مؤكسدا" اذ اذ يتكون معقدا" يكون ذائبا' بالماء ومسنقرا' ويعطي اعلى لمتصاص عند الطول الموجي الاعظم 459 نانوميتر. كانت حدود قانون

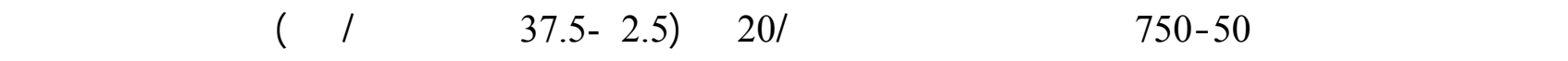

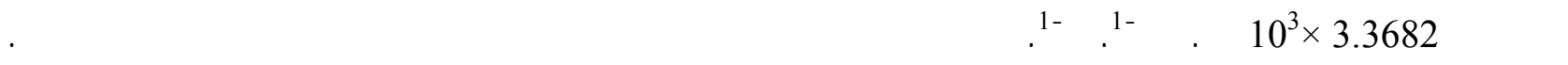

الهاملت الدالة:طيفي، اقتران تلكسدي، ميزالازين، هستني.

INTRODUCTION

Mesalazine (MESA), also named mesalamine, its chemical name is 5-amino-2-hydroxy benzoic acid. The powder or crystals of MESA has a white or light grey or light pink color(British pharmacopia, 2013) .It is soluble in dil.acidic and alkaline medium, fairly insoluble in chloroform, ether, ethyl acetate and n-hexane. (Moharana et al., 2011).

MESA has been determined by different kinds of analytical techniques in various formulations and some biological liquids these involve: HPLC (Darak et al., 2012), RP-HPLC (Rao and Sekhar, 2013), UHPLC-MS/MS (Banda et al., 2016), electrochemical studies by CV technique (Tanuja et al., 2018) and spectrofluorimetric technique (Elbashir et al., 2015). Also, MESA has been estimated by various spectrophotometric methods in pure form and drugs formulations by various reagents for example 1,2-Naphthoquinone-4-sulphonate (NQS), p- dimethyl amino cinnamaldehyde (PDAC) (Gurupadayya et al., 2010), a solution of $\mathrm{Fe}\left(\mathrm{NO}_{2}\right)_{3}$ in presence of $\mathrm{HCl}$ (Moharana et al., 2011), Ortho-Chloranil (Al-Enizzi et al., 2012), 1,5-diphenyl carbazide (1,5-DPC) (Hamdoon, 2018), 8-hydroxyquinoline and N-(1-naphthyl)ethylenediamine (Zakaria, 2013), sodium nitroprusside with hydroxylamine hydrochloride (Al-Sabha and Habeb, 2015). Also MESA has been estimated in a Ultraviolet region (Mhatre et al., 2013). 
The suggested method gives good results for estimation MESA in pure and drugs formulations by oxidation with $\mathrm{N}$ - bromosuccinimide then coupling the product with histidine in alkaline medium, the formed colored complex prove to be intense, water-soluble and stable.

\section{Instruments}

\section{EXPERIMENTAL}

The UV Spectrophotometer was used (JascoV-630) and a pair of silica cells were used for all experiments, also the $\mathrm{pH}$ of solution was estimated by $\mathrm{pH}$ meter type HANA .

\section{Analytical reagents were used in this work}

Standard MESA solution, $500 \mu \mathrm{gg} \cdot \mathrm{ml}^{\mathbf{1}}$. A $0.05 \mathrm{~g}$ of MESA (Fluka) was dissolved in $10 \mathrm{ml}$ of absolute ethanol and diluted to $100 \mathrm{ml}$ distilled water using a volumetric flask.

Histidine(HIS) solution, 0.01M. A $0.1551 \mathrm{~g}$ of HIS was dissolved in $100 \mathrm{ml}$ distilled water using a volumetric flask.

N-bromosuccinimide(NBS) solution, 0.015M. Accurate weight of $0.2669 \mathrm{~g}$ of NBS was dissolved in $100 \mathrm{ml}$ distilled water using a volumetric flask.

Sodium hydroxide solution, 1N. A concentrated solution (10N, fluka) was diluted to $1000 \mathrm{ml}$ distilled water in a volumetric flask then transported to plastic container.

Pharmaceutical preparation. An accurate weight (equivalent to $0.05 \mathrm{~g}$ MESA) of the powder for ten tablets was dissolved in $10 \mathrm{ml}$ absolute ethanol and the volume completed to $100 \mathrm{ml}$ by distilled water in a volumetric flask.

\section{General method and calibration graph}

To $20 \mathrm{ml}$ volumetric flasks, $0.1-2 \mathrm{ml}$ of MESA solution $(500 \mu \mathrm{g} / \mathrm{ml})$ were transported, then 1 $\mathrm{ml}$ of HIS $(0.01 \mathrm{M}), 0.5 \mathrm{ml}$ of NBS $(0.015 \mathrm{M})$ and $1 \mathrm{ml} \mathrm{NaOH}(1 \mathrm{~N})$ were added. The solutions were left to stand for 15 minutes before completing the volumetric flasks with distilled water. The measured absorbance's against the reagent blank were done at $459 \mathrm{~nm}$ and Beer's law was applied from 50-750 $\mu \mathrm{g}$ MESA / 20ml Fig. (1). From the eqution of straight line, the molar absorbtivity was $3.368 \times 10^{3} 1 . \mathrm{mol}^{-1} . \mathrm{cm}^{-1}$.

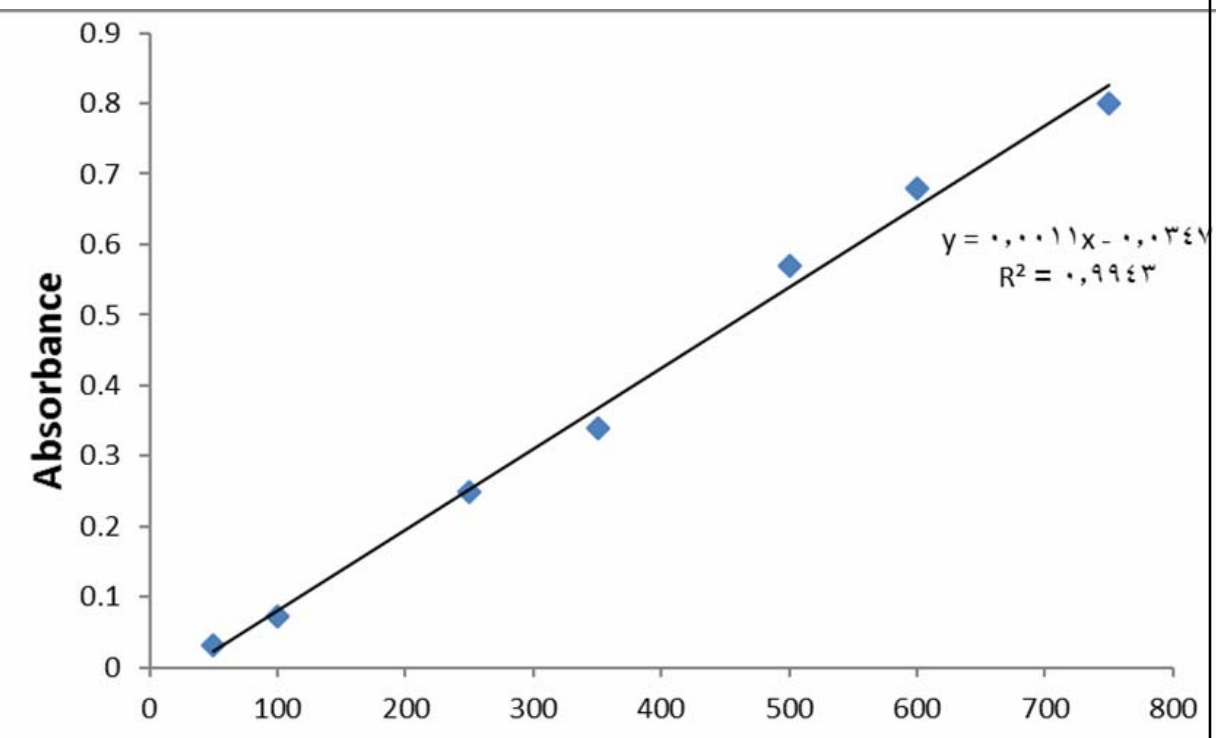

Hg MESA/20ml

Fig. 1: Calibration graph for determination of MESA using the proposed method. 


\section{RESULTS AND DISCUSSION}

All factors affected on the color development for $500 \mu \mathrm{g}$ MESA in $20 \mathrm{ml}$ were investigated.

\section{Principle of the Method}

The method included two steps:

1-Oxidation of MESA by NBS to produce MESA derivative (DMESA)

$1-$

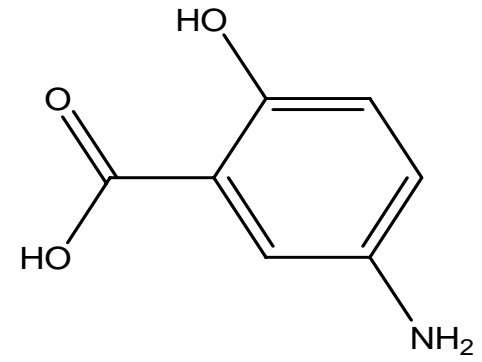

MESA

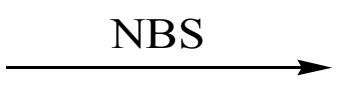

2-The coupling of DMESA with histidine in alkaline medium to produce orange dye.

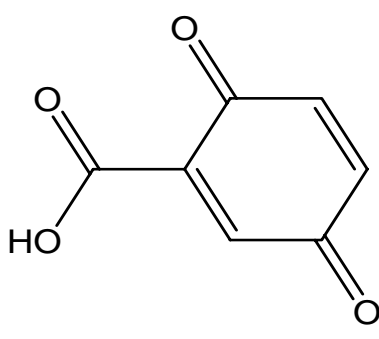

DMESA<smiles>NC(Cc1c[nH]cn1)C(=O)O</smiles>

His
DMESA

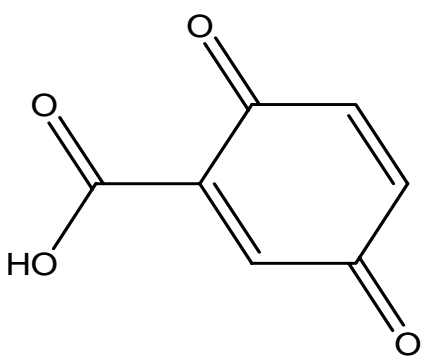

Choosing of Oxidizing Agent

The best one of oxidizing agents which give the highest intensity was selected after studying different types of available oxidizing agents (Table 1)

\section{Table 1: Selection of oxidizing agent}

\begin{tabular}{|c|c|c|}
\hline $\begin{array}{c}\text { Oxidizing agent } \\
(1 \mathrm{ml} \text { of } 0.015 \mathrm{M}) \text { soln. }\end{array}$ & Absorbance & $\Delta \lambda$ \\
\hline $\mathrm{NaIO}_{4}$ & 0.262 & 166 \\
\hline $\mathrm{KIO}_{3}$ & \multicolumn{2}{|c|}{ (Bad result)No color contrast } \\
\hline $\mathrm{K}_{2} \mathrm{CrO}_{4}$ & \multicolumn{2}{|c|}{ (Bad result)No color contrast } \\
\hline $\mathrm{K}_{2} \mathrm{Cr}_{2} \mathrm{O}_{7}$ & \multicolumn{2}{|c|}{ (Bad result)No color contrast } \\
\hline NCS & 0.215 & 195 \\
\hline NBS & 0.408 & 168 \\
\hline Ammonium cerium(IV) sulfate & \multicolumn{2}{|c|}{ (Bad result) turbid } \\
\hline
\end{tabular}

$$
\Delta \lambda=\lambda_{\text {max }} \mathrm{S}-\lambda_{\max } \mathrm{B} \quad \mathrm{S}=\text { Dye } \quad \mathrm{B}=\mathrm{Blank}
$$

Results illustrated in Table 1 show that NBS gave the highest intensity and a good color contrast for colored product. 


\section{The medium of Present Reaction}

The primarily experiment has shown that reaction of MESA with HIS in presence of NBS needs alkaline medium, therefor various types of bases were studied (Table 2 ).

Table 2: Choosing suitable base

\begin{tabular}{|c|c|c|}
\hline Base (1ml of 1N) & Absorbance & $\Delta \lambda$ \\
\hline $\mathrm{NaOH}$ & 0.404 & 167 \\
\hline $\mathrm{KOH}$ & 0.385 & 134 \\
\hline $\mathrm{Na}_{2} \mathrm{CO}_{3}$ & 0.296 & 129 \\
\hline $\mathrm{NaHCO}_{3}$ & 0.202 & 135 \\
\hline
\end{tabular}

Results in (Table 2) show that a certain alkaline medium was needed and $\mathrm{NaOH}$ gave the best results with volume equal to $1 \mathrm{ml}$ (Table 3).

Table 3: Effect of base amount on absorbance

\begin{tabular}{|c|c|c|c|c|c|c|}
\hline $\begin{array}{c}\text { NaOH solution } \\
\text { (ml of 1N) }\end{array}$ & $\mathbf{0}$ & $\mathbf{0 . 5}$ & $\mathbf{1}$ & $\mathbf{1 . 5}$ & $\mathbf{2}$ & $\mathbf{3}$ \\
\hline Absorbance & 0.385 & 0.409 & 0.430 & 0.375 & 0.369 & 0.336 \\
\hline $\mathrm{pH}$ & 6.30 & 12.27 & 12.63 & 12.75 & 12.86 & 12.92 \\
\hline
\end{tabular}

\section{Effect of HIS Reagent Concentration}

The effect of HIS amount on the color intensity of the dye has been studied. From the results, it can be observed that $1 \mathrm{ml}$ of $0.01 \mathrm{M}$ HIS is the most suitable amount which gave the highest intensity of color and highest value of correlation coefficient (Table 4).

Table 4: Effect of HIS amount

\begin{tabular}{|c|c|c|c|c|c|c|}
\hline \multirow{2}{*}{$\begin{array}{c}\text { HIS solution } \\
(\mathbf{m l} \text { of 0.01M) }\end{array}$} & \multicolumn{7}{|c|}{ Absorbance/ $\boldsymbol{\mu g}$ of MESA } \\
\cline { 2 - 7 } & $\mathbf{2 0 0}$ & $\mathbf{3 0 0}$ & $\mathbf{4 0 0}$ & $\mathbf{5 0 0}$ & $\mathbf{6 0 0}$ & $\mathbf{R}$ \\
\hline 0.5 & 0.054 & 0.105 & 0.121 & 0.168 & 0.223 & 0.9875 \\
\hline 1 & 0.095 & 0.210 & 0.296 & 0.434 & 0.482 & 0.9922 \\
\hline 1.5 & 0.122 & 0.210 & 0.247 & 0.399 & 0.447 & 0.9816 \\
\hline 2 & 0.148 & 0.213 & 0.23 & 0.328 & 0.368 & 0.9825 \\
\hline
\end{tabular}

\section{Effect of NBS Amount on Absorbance}

The effect of various volumes of NBS solution $(0.015 \mathrm{M})$ on the color intensity has been studied. A $0.5 \mathrm{ml}$ of NBS was the optimum amount which gave the highest intensity of color and highest value of correlation coefficient (Table 5).

Table 5: Effect of NBS amount on absorbance

\begin{tabular}{|c|c|c|c|c|c|c|}
\hline \multirow{2}{*}{$\begin{array}{l}\text { NBS solution(ml } \\
\text { of0.015M) }\end{array}$} & \multicolumn{6}{|c|}{ Absorbance/ $\mu \mathrm{g}$ of MESA } \\
\hline & 200 & 300 & 400 & 500 & 600 & $\mathrm{R}$ \\
\hline 0.3 & 0.125 & 0.133 & 0.284 & 0.262 & 0.285 & 0.8696 \\
\hline 0.5 & 0.151 & 0.196 & 0.363 & 0.496 & 0.644 & 0.9885 \\
\hline 1 & 0.085 & 0.198 & 0.302 & 0.439 & 0.463 & 0.9848 \\
\hline
\end{tabular}

\section{The Effect of Time on Oxidation of MESA}

Only 15 minutes was needed to complete the oxidation process before completing the volume with distilled water (Table 6). 
Table 6: Effect of time

\begin{tabular}{|l|c|c|c|c|c|}
\hline Time, minutes & $\mathbf{0}$ & $\mathbf{5}$ & $\mathbf{1 0}$ & $\mathbf{1 5}$ & $\mathbf{2 0}$ \\
\hline Absorbance & 0.478 & 0.502 & 0.533 & 0.569 & 0.552 \\
\hline
\end{tabular}

\section{Effect of Surfactant}

The results in Table (7) showed that no effect of surfactant on the intensity (Table 7).

\section{Table 7: Effect of surfactant}

\begin{tabular}{|c|c|c|c|c|c|c|c|c|}
\hline \multirow{3}{*}{$\begin{array}{c}3 \mathrm{ml} \\
\text { Surfactant } \\
\text { Solution }\end{array}$} & \multicolumn{8}{|c|}{ Absorbance/order of addition } \\
\hline & \multicolumn{2}{|c|}{$I^{*}$} & \multicolumn{2}{|c|}{ II } & \multicolumn{2}{|c|}{ III } & \multicolumn{2}{|c|}{ IV } \\
\hline & $\mathbf{A}$ & $\Delta \lambda$ & $\mathbf{A}$ & $\Delta \lambda$ & $\mathbf{A}$ & $\Delta \lambda$ & $\mathbf{A}$ & $\Delta \lambda$ \\
\hline $\begin{array}{c}\text { CTAB } \\
1 \times 10^{-3} \mathrm{M}\end{array}$ & 0.189 & 262 & 0.208 & 179 & 0.277 & 159 & 0.383 & 161 \\
\hline $\begin{array}{c}\text { SDS } \\
1 \times 10^{-3} \mathrm{M} \\
\end{array}$ & 0.545 & 169 & 0.560 & 170 & 0.473 & 169 & 0.367 & 169 \\
\hline $\begin{array}{c}\text { Triton } \mathrm{x}-100 \\
1 \%(\mathrm{wt} / \mathrm{v})\end{array}$ & 0.544 & 170 & 0.527 & 172 & 0.509 & 170 & 0.391 & 172 \\
\hline Without & 0.564 & & & & & & & \\
\hline
\end{tabular}

I* $\mathrm{MESA}+\mathrm{S}+\mathrm{HIS}+\mathrm{NBS}+\mathrm{NaOH}$

II $\mathrm{MESA}+\mathrm{HIS}+\mathrm{S}+\mathrm{NBS}+\mathrm{NaOH}$

III MESA+HIS+NBS+S+NaOH

IV MESA+HIS+NBS+NaOH+S

\section{The Best Order of Addition}

The optimum order of reagent addition be followed as given under the general procedure because it gives highest color intensity, otherwise a loss in color intensity occurred (Table 8).

Table 8: The order of addition

\begin{tabular}{|c|l|c|}
\hline Order number & Order of addition & Abs. \\
\hline I & MESA+HIS+NBS+OH & 0.569 \\
\hline II & NBS+MESA+HIS+OH & 0.228 \\
\hline III & NBS+HIS+MESA+OH & 0.144 \\
\hline IV & MESA+HIS+OH+NBS & 0.209 \\
\hline V & OH+NBS+MESA+HIS & 0.485 \\
\hline VI & OH+NBS+HIS+MESA & 0.092 \\
\hline VII & HIS+NBS+OH+MESA & 0.357 \\
\hline VIII & MESA+NBS+OH+HIS & 0.238 \\
\hline
\end{tabular}

\section{The stability period} 4 hours.

The experimental results (Table 9) showed that the absorbance remained constant at least for

Table 9: Effect of color stability time

\begin{tabular}{|c|c|c|c|c|c|c|c|c|c|}
\hline \multirow{2}{*}{$\boldsymbol{\mu g}$ of MESA } & \multicolumn{9}{|c|}{ Abs./ min. standing time } \\
\cline { 2 - 12 } & $\mathbf{5}$ & $\mathbf{1 0}$ & $\mathbf{1 5}$ & $\mathbf{2 0}$ & $\mathbf{3 0}$ & $\mathbf{4 0}$ & $\mathbf{5 0}$ & $\mathbf{6 0}$ & $\mathbf{4}$ hours \\
\hline $\mathbf{2 5 0}$ & 0.270 & 0.270 & 0.270 & 0.270 & 0.270 & 0.270 & 0.270 & 0.270 & 0.270 \\
\hline $\mathbf{5 0 0}$ & 0.571 & 0.570 & 0.570 & 0.570 & 0.571 & 0.570 & 0.572 & 0.573 & 0.573 \\
\hline $\mathbf{6 0 0}$ & 0.687 & 0.687 & 0.687 & 0.685 & 0.686 & 0.685 & 0.686 & 0.686 & 0.686 \\
\hline
\end{tabular}

\section{Final absorption spectrum}

When MESA was treated according to the suggested work, the absorption spectrum, showed a maximum absorption at $459 \mathrm{~nm}$ versus the blank solution Fig. (2). 


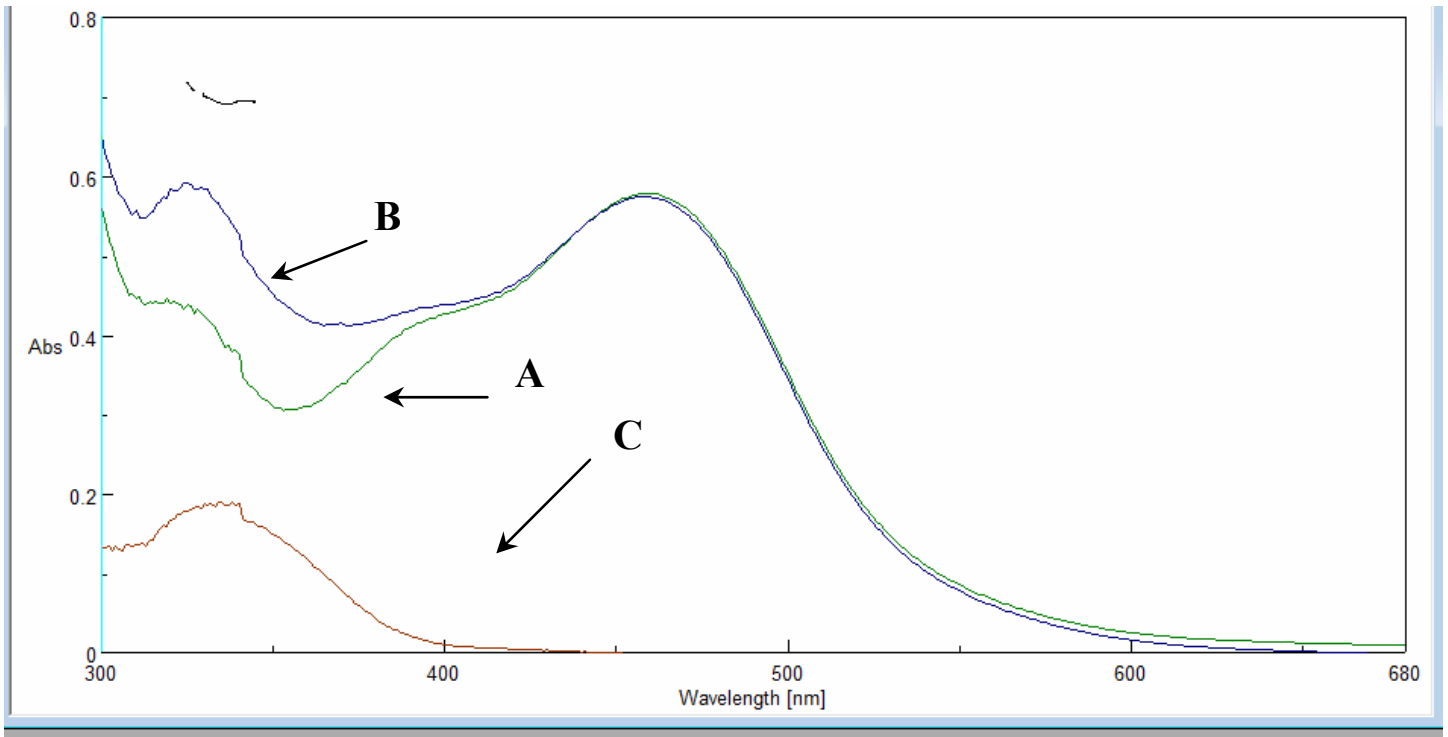

Fig. 2: Absorption spectrum of the colored product $500 \mu \mathrm{g}$ MESA (A) against blank, (B) against distilled water and $(\mathrm{C})$ blank against distilled water.

The Nature of the Reaction Product

Jobs of the continuous variation (Delvie, 1997). Fig. (3) indicate that a colored product has a structure of 1:2 MESA to HIS reagent at $459 \mathrm{~nm}$.

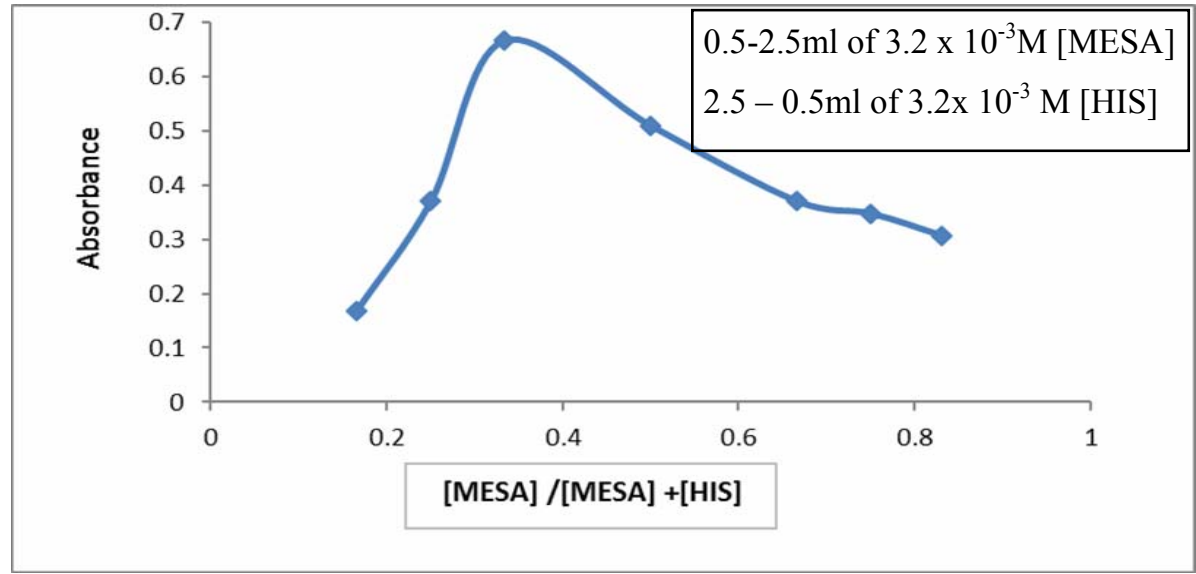

Fig. 3: Job' plot for MESA-HIS colored product

Therefore, the probable colored product have the below structure:

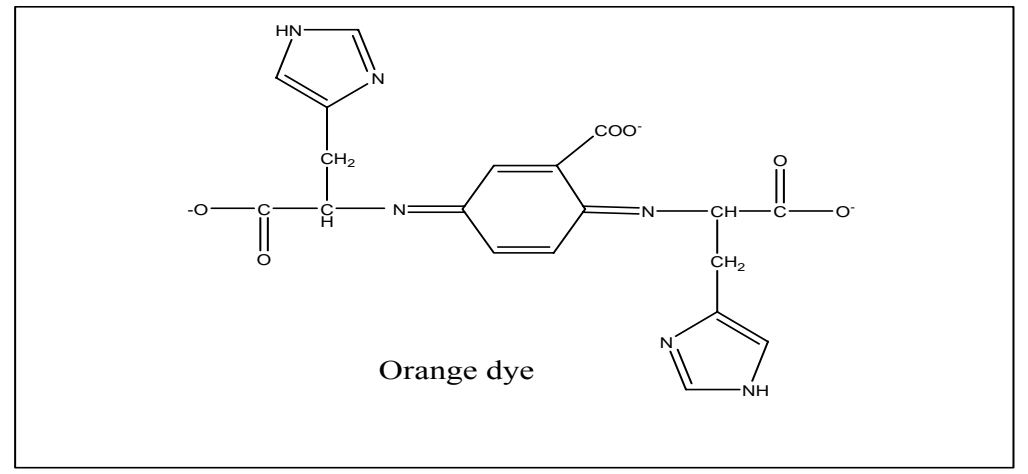




\section{Application of the Method}

To test the applicability of the present method, it has been applied to estimate MESA in drug formulation (tablet). On applying proposed procedure, a good recovery, accuracy and precision are obtained as shown in (Table 10).

\section{Table 10: Application of method}

\begin{tabular}{|c|c|c|c|c|c|}
\hline Drug & $\begin{array}{c}\mu \mathrm{g} \text { MESA } \\
\text { present } / 20 \mathrm{ml}\end{array}$ & $\begin{array}{c}\mu \mathrm{g} \text { MESA } \\
\text { measured } / 20 \mathrm{ml}\end{array}$ & Recovery $^{*}, \%$ & $\begin{array}{l}\text { Relative } \\
\text { error*\% } \%\end{array}$ & $\begin{array}{c}\text { Relative } \\
\text { standard } \\
\text { deviation" } \%\end{array}$ \\
\hline \multirow{3}{*}{$\begin{array}{c}\text { Pentasa tablets } \\
500 \mathrm{mg} \\
\text { Ferring } \\
\end{array}$} & 200 & 193.8 & 96.9 & 3.1 & \pm 0.40 \\
\hline & 400 & 397.3 & 99.3 & 0.7 & \pm 0.17 \\
\hline & 500 & 495.5 & 99.1 & 0.9 & \pm 1.25 \\
\hline \multirow{3}{*}{$\begin{array}{c}\text { Mezelazin tablets } \\
400 \mathrm{mg} \\
\text { Awa media } \\
\end{array}$} & 200 & 202.3 & 101.1 & -1.1 & \pm 0.87 \\
\hline & 400 & 396.5 & 99.0 & 1.0 & \pm 0.37 \\
\hline & 500 & 503.0 & 100.6 & -0.6 & \pm 0.40 \\
\hline
\end{tabular}

*Average of four determinations

\section{Comparison of method}

Table (11) shows the comparison between the various analytical parameters found in suggested work with other spectrophotometric methods.

\section{Table 11: Comparison with other methods}

\begin{tabular}{|c|c|c|c|}
\hline Analytical parameters & Suggested work & $\begin{array}{c}\text { Method (1) (Shihab, } \\
\text { 2011) } \\
\end{array}$ & $\begin{array}{c}\text { Method (2) (Zakaria, } \\
\text { 2009) } \\
\end{array}$ \\
\hline$\lambda_{\max }(\mathrm{nm})$ & 459 & 530 & 471 \\
\hline Beer's law range(ppm) & $2.5-37.5$ & $0.4-10$ & $0.4-12$ \\
\hline $\begin{array}{c}\text { Molar absorptivity } \\
\text { l.mol }{ }^{-1} \cdot \mathrm{cm}^{-1}\end{array}$ & 3368.2 & 3685 & 29480 \\
\hline $\begin{array}{c}\begin{array}{c}\text { Stability of the color } \\
\text { (minutes) }\end{array} \\
\end{array}$ & 240 & 65 & 60 \\
\hline Medium of method & Alkaline & Acidic & Alkaline \\
\hline Reagent & Hisitidine & Pyrocatechol & Resorcinol \\
\hline Type of reaction & Oxidative coupling & Oxidative coupling & Diazotisation \\
\hline Nature of the dye & $1: 2$ & $1: 1$ & $1: 1$ \\
\hline Application part & $\begin{array}{l}\text { Determination of MESA } \\
\text { in tablets }\end{array}$ & $\begin{array}{c}\text { Determination of MESA } \\
\text { in tablets and capsules }\end{array}$ & $\begin{array}{c}\text { Determination of MESA in } \\
\text { capsules }\end{array}$ \\
\hline
\end{tabular}

The proposed method is a simple, rapid, sensitive, more stable and can be used to determine MESA in drugs formulations.

\section{CONCLUSION}

A simple, sensitive and rapid spectrophotometric method for estimating MESA in aqueous solution has been carried out by the reaction of MESA with HIS in presence of NBS in alkaline medium. The suggested work has been successfully applied to determine MESA in pharmaceutical preparation (Tablets).

\section{REFERENCES}

Al-Enizzi, M.S.; Al-Sabha, T.N.; Al-Ghabsha, T.S. (2012). Use of charge transfer complex formation reaction in spectrophotometric micro determination of some drugs. Jordan $J$. Chem., 7(1), 87-102. 
Al-Sabha, T.N.; Habeeb, N.N. (2015). Spectrophotometric determination of mesalamine using sodium nitroprusside as chromogenic reagent. European Chem. Bulletin, 4,7-9.

Balaji, J.; Shivashankar, M. (2017). Development and validation of RP-UHPLC procedure for estimation of 5-aminosalicyclic acid in rectal suppositories. Materials Sci. Engi., 263.

Banda, J.; Lakshmanan, R.; Katepalli, R.P.; Venati, U.K.R.; Koppula, R.; Shiva Prasad, V.V.S. (2016). Determination of mesalazine, a low bioavailability olsalazine metabolite in human plasma by UHPLC-MS/MS: Application to a pharmacokinetic study. J. Chromatography $B, 1008,1-10$.

British Pharmacopia (2013). "Her Majesty's". The Stationery Office. London.

Darak, V.; Karadi, A.; Raju, S.; Arshard, M.D.; Ganure, A. (2012). Development and validation of HPLC method for determination of mesalazine in tablet dosage forms. Pharma. Sci. Monitor an Int. J. Pharma. Sci., 3(1), 74-81.

Delvie, R. (1997). "Principles of Quantitative Chemical Analysis". International ed., The McGrawHill Inc., Singapore, p.498.

Elbashir, A.A.; Abdalla, F.A.A.; Aboul-Enein, H.Y. (2015). Supramolecular interaction of 18crown-6 ether with mesalazine and spectrofluorimetric determination of mesalazine in pharmaceutical formulations. J. Biol. Chem. Luminescence, 30(8), 1250-1256.

Gurupadayya, B.M.; Sama, N.S.; Kumar, C.A. (2011). Spectrophotometric determination of mesalamine by PDAC and NQS reagents in bulk and tablet dosage form. J. Pharmacy Research, 4(1), 39-41.

Hamdoon, E.A. (2018). Indirect spectrophotometric determination of mesalazine via chromate-1,5diphenyl carbazide complex. Raf. J. Sci., 27(3), 69-78.

Mhatre, P.R.; Gatkal, S.H.; Chopade, V.V.; Chaudhari, P.D. (2013). Development and validation of a stability indicating assay method of mesalamine by using different stress degradation conditions. Int. J. Pharm. Sci. Res., 4(1), 401-406.

Moharana, A.K.; Banerjee, M.; Sahoo, N.K. (2011). Development and validation of visible spectroscopic method for the determination of mesalamine in Bulk and tablet formulation. Asian J. Research in Chem., 4(4), 647-649.

Rao, K.H.; Sekhar, KB.C. (2013). Validated RP-HPLC method for the estimation of mesalamine in bulk and tablet dosage form. International J. Research in Pharm. Chem., 3(2), 472-476.

Shihab, I.A. (2011). Spectrophotometric determination of mesalazine via oxidative coupling reaction. Tikrit. J. Pur. Sci., 16(4), 64-69.

Tanuja, S. B.; Swamy, B. E. K.; Pai, K.V. (2018). Electrochemical studies of mesalazine at sodium dodecyl sulfate modified carbon paste electrode: A cyclic voltammetric study. Anal. Bioanal. Electrochem., 10(1), 64-76.

Zakaria, R.A. (2009). Spectrophotometric determination of mesalazine by diazotization coupling method with resorcinol. Raf. J. Sci., 20(1), 90-104.

Zakaria, R.A. (2013). Spectrophotometric determination of mesalazine by 8- Hydroxyquinoline and $\mathrm{N}$-(1-naphthyl) ethylenediamine. dihydrochloride reagents in bulk and capsule dosage forms. Raf. J. Sci., 24(1), 146-158. 